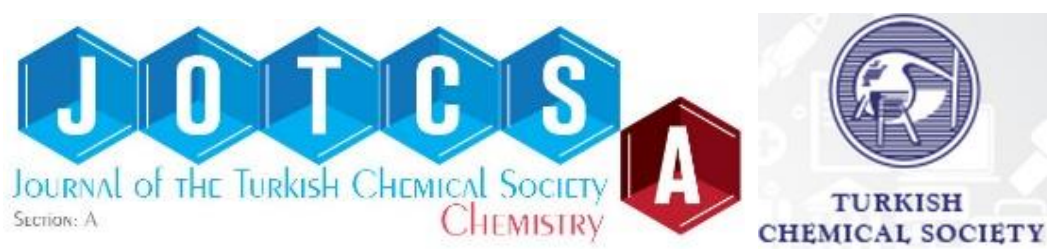

\title{
Synthesis and Characterization of New Cyclic Aminobenzoquinones
}

\author{
Amaç Fatih Tuyun', $*$ and Mahmut Yıldız \\ ${ }^{1}$ Istanbul University, Engineering Faculty, Engineering Sciences Department, 34320 Avcılar, \\ Istanbul, Turkey \\ ${ }^{2}$ Gebze Technical University, Chemistry Department, Gebze, 41400, Kocaeli, Turkey
}

\begin{abstract}
The aim of this research is to synthesize and characterize new members of cyclic aminobenzoquinones. Mono amino substituted products, namely 2-chloro-5,6-dimethyl-3(pyrrolidin-1-yl)-1,4-benzoquinone (2), 2-chloro-5,6-dimethyl-3-(piperidin-1-yl)-1,4benzoquinone (3), 2-chloro-5,6-dimethyl-3-morpholino-1,4-benzoquinone (4), and 2-chloro-5,6dimethyl-3-thiomorpholino-1,4-benzoquinone (5) have been synthesized by the nucleophilic substitution reactions between 2,3-dichloro-5,6-dimethyl-1,4-benzoquinone (1) and cyclic secondary amines with a green methodology using water as solvent. Structure determination of the new products (2-5) was established on the basis of FTIR, ${ }^{1} \mathrm{H} N M R,{ }^{13} \mathrm{C} N M R$, and mass spectrometry.
\end{abstract}

Keywords: Benzoquinones, secondary amine, aminoquinones.

Submitted: November 2, 2017. Accepted: February 06, 2018.

Cite This: Tuyun AF, Yıldız M. Synthesis and Characterization of New Cyclic Aminobenzoquinones. JOTCSA. 2018;5(2):371-80.

DOI: http://dx.doi.org/10.18596/jotcsa.348606.

*Corresponding author. E-mail:aftuyun@gmail.com 


\section{INTRODUCTION}

Compounds containing quinone core exist widely in nature (plants, microorganisms, animals, etc.) and have been utilized by mankind during many years $(1,2)$. These structures could be either isolated from natural products or synthesized in the laboratories by applying various experimental methods (3-8). Plenty of molecules which belong to quinone family are particularly biologically active compounds and possess antitumor, cytotoxic, anticancer, antimalarial, and antifungal properties (9-13). These type of compounds can also find potential application as the electrondeficient compounds in heterocyclic synthesis, a generator of reactive oxygen species in photodynamic therapies, the organic electrode materials in lithium-ion batteries, a chemosensor in metal detection analyses, and the quinone oligomers in the field of DNA sensors $(2,14-21)$.

The reactions of quinones with a variety of amines give aminoquinone compounds (22-24). Particularly, aminoquinone structures draw interest in the literature because of the similar biological characteristics to quinone moieties $(5,23,25-36)$. Although they have numerous beneficial biological activities, quinone structures including pharmacophore groups could sometimes cause possible toxic effects in in vivo implementations. However, Zakharova et al. have investigated also the cytotoxicity of new polyfluorinated 1,4-naphthoquinones and indicated that a number of synthesized structures exhibited a substantial cytotoxic effect against cancer cells compared to normal mammalian cells (36). Moreover, Khodade et al. have suggested that there is a good correlation between reactive oxygen species production of 2-aryl-3-amino-1,4-naphthoquinones and their DNA damage inducing ability (37). Besides that, Sharma et al. showed a new synthesis of 2-aryl-3-amino-1,4-naphthoquinones by using an eco-friendly, non-toxic, efficient, inexpensive, and reusable $\mathrm{HClO}_{4}-\mathrm{SiO}_{2}$ heterogeneous catalyst which is applied to different organic reactions (29). In a study reported by Verma et al. in 2015, some metal complexes of 2-chloro-3-amino-1,4naphthoquinone derivatives with $\mathrm{Mn}, \mathrm{Co}, \mathrm{Ni}, \mathrm{Cu}$, and $\mathrm{Zn}$ metals were synthesized and characterized. The complex compounds exhibited a promising antimicrobial activity and fluorescence emission behavior and they were also found as electro active compounds (35). Nitrogen and sulfur containing quinones known also sulfanyl aminoquinones in the literature are of great importance in drug exploration researches due to their bioactive properties (13,38-43). Recently, new sulfanyl and arylamine substituted 1,4-naphthoquinones have been synthesized and characterized $(44,45)$.

Encouraged by the previous studies and taking into account the well-documented quinone chemistry associated with the 1,4-benzoquinone pharmacophoric unit, it was attempted to synthesize several new cyclic aminobenzoquinone compounds. Thus, as a part of our research, aiming at the discovery of novel biologically active molecules based on 1,4-benzoquinone moiety, we have recently reported 
the synthesis and characterization of cyclic aminobenzoquinones which contain a heterocyclic fragment as a key structural element.

\section{MATERIALS AND METHODS}

All reagents used were purchased from the various commercial supplier. Reactions were monitored by TLC performed on silica gel plate purchased from Merck KGaA (silica gel $60 \mathrm{~F}_{254}$ ) based on Merck DC-plates (aluminum-based) and visualization was achieved by UV light (254 nm). Column chromatography was performed with silica gel 60 (Merck, 63-200 $\mu \mathrm{m}$ particle size, 60-230 mesh). ${ }^{1} \mathrm{H}$ NMR and ${ }^{13} \mathrm{C}$ NMR spectra (VarianUNITY INOVA spectrometers $500 \mathrm{MHz}$ frequency for ${ }^{1} \mathrm{H}$ and $125 \mathrm{MHz}$ frequency for ${ }^{13} \mathrm{C}$ NMR) and Fourier transform infrared (FT-IR) spectra as ATR (Thermo Scientific Nicolet 6700 spectrometer) were used to elucidate the structures of the products. Chemical shifts are expressed in parts per million ( $\delta$ in $\mathrm{ppm})$ and coupling constants are expressed in $\mathrm{Hz} .{ }^{1} \mathrm{H}$ NMR spectroscopic data are used as follows: s (singlet), d (doublet), t (triplet), q (quartet), and $\mathrm{m}$ (multiplet). Mass spectra were recorded with either a Thermo Finnigan LCQ Advantage MAX MS/MS spectrometer equipped with ESI (electrospray ionization) sources or a BRUKER Microflex LT by MALDI (Matrix Assisted Laser Desorption Ionization)-TOF (Time of Flight) technique via addition of 1,8,9-anthracenetriol (DIT, dithranol) as matrix. The 2,3-dichloro-5,6-dimethyl-1,4benzoquinone (1) was prepared according to the literature reported previously and the reference cited therein (46).

\section{General Procedure for Synthesis of the Cyclic Aminobenzoquinone Derivatives (2-5)}

The mixture of 2,3-dichloro-5,6-dimethyl-1,4-benzoquinone $(\mathbf{1}, 0.5 \mathrm{mmol})$ in water $(10 \mathrm{~mL})$ and cyclic secondary amines $(1.1 \mathrm{mmol})$ was stirred at $50-60{ }^{\circ} \mathrm{C}$ for 6 to $18 \mathrm{~h}$ as stated in the literature (42). The resulting solution was extracted with $100 \mathrm{~mL}$ chloroform, and then was washed with water $(4 \times 25 \mathrm{~mL})$ and dried over calcium chloride. The solvent was removed in vacuo. The residue was subjected to column chromatography on silica gel using suitable solvents to give the products (25).

2-Chloro-5,6-dimethyl-3-(pyrrolidin-1-yl)-1,4-benzoquinone (2). Following general procedure by applying pyrrolidine $(0.076 \mathrm{~g}, 1.07 \mathrm{mmol})$, the crude residue was purified by column chromatography to furnish 2 as purple oil. Yield: 71\%. FTIR (ATR) U (cm-1): 2919, $2850\left(\mathrm{CH}_{\text {aliphatic }}\right)$, 1661 (>C=0). ${ }^{1} \mathrm{H}$ NMR $\left(\mathrm{CDCl}_{3}\right) \delta(\mathrm{ppm}): 1.80-1.82\left(\mathrm{~m}, 4 \mathrm{H}, \mathrm{H} 10\right.$ and $\left.\mathrm{H} 10^{\prime}\right), 1.89$ (dd, $J=1.13$ and $2.33 \mathrm{~Hz}, 3 \mathrm{H}, \mathrm{H} 8$ ), 1.99 ( $\mathrm{dd}, J=1.17$ and $2.37 \mathrm{~Hz}, 3 \mathrm{H}, \mathrm{H} 7), 3.78-3.81\left(\mathrm{~m}, 4 \mathrm{H}, \mathrm{H} 9\right.$ and $\left.\mathrm{H}^{\prime}\right)$. ${ }^{13} \mathrm{C}$ NMR $\left(\mathrm{CDCl}_{3}\right) \delta(\mathrm{ppm}): 11.4,12.2$ (C7 and C8), 24.7 (C10 and $\left.\mathrm{C} 10^{\prime}\right), 52.7$ (C9 and C9'), 107.6, $135.8,140.8,146.0(\mathrm{C} 2, \mathrm{C} 3, \mathrm{C} 5$, and C6), 178.2, 184.2 (C1 and C4). MS (+ESI) m/z (\%): 240 (27, $\left.[\mathrm{M}+\mathrm{H}]^{+}\right), 238\left(10,[\mathrm{M}-\mathrm{H}]^{+}\right)$. Calcd. for $\mathrm{C}_{12} \mathrm{H}_{14} \mathrm{ClNO}_{2}(239.70)$. 
2-Chloro-5,6-dimethyl-3-(piperidin-1-yl)-1,4-benzoquinone (3). Following general procedure by applying piperidine $(0.091 \mathrm{~g}, 1.07 \mathrm{mmol})$, the crude residue was purified by column chromatography to furnish 3 as purple oil. Yield: 57\%. FTIR (ATR) u $\left(\mathrm{cm}^{-1}\right)$ : 2934, 2853 ( $\left.\mathrm{CH}_{\text {aliphatic }}\right), 1657(>\mathrm{C}=\mathrm{O})$. ${ }^{1} \mathrm{H} \mathrm{NMR}\left(\mathrm{CDCl}_{3}\right) \delta(\mathrm{ppm}): 1.60-1.64\left(\mathrm{~m}, 6 \mathrm{H}, \mathrm{H} 10, \mathrm{H} 10^{\prime}\right.$, and $\left.\mathrm{H} 11\right), 1.92(\mathrm{~m}, 3 \mathrm{H}, \mathrm{H} 8), 1.98(\mathrm{~m}, 3 \mathrm{H}$, $\mathrm{H} 7)$, 3.33-3.35 (m, 4H, $\mathrm{H} 9$ and $\left.\mathrm{H}^{\prime}\right) .{ }^{13} \mathrm{C} \mathrm{NMR}\left(\mathrm{CDCl}_{3}\right) \delta(\mathrm{ppm}): 11.6,12.1$ (C7 and C8), 23.1, 25.8 (C10, C10', and C11), 51.6 (C9 and C9'), 117.6, 137.5, 140.2, 147.9 (C2, C3, C5, and C6), 179.1, 183.1 ( $\mathrm{C} 1$ and C4). MS (MALDI TOF) $\mathrm{m} / \mathrm{z}: 252[\mathrm{M}-\mathrm{H}]^{+}$. Calcd. for $\mathrm{C}_{13} \mathrm{H}_{16} \mathrm{CINO}_{2}$ (253.72).

2-Chloro-5,6-dimethyl-3-morpholino-1,4-benzoquinone (4). Following general procedure by applying morpholine $(0.093 \mathrm{~g}, 1.07 \mathrm{mmol})$, the crude residue was purified by column chromatography to furnish 4 as dark red oil. Yield: 29\%. FTIR (ATR) U (cm-1): 2966, 2916, 2854 ( $\left.\mathrm{CH}_{\text {aliphatic }}\right), 1656$ (>C=0). ${ }^{1} \mathrm{H}$ NMR $\left(\mathrm{CDCl}_{3}\right) \delta(\mathrm{ppm}): 1.93(\mathrm{dd}, \mathrm{J}=1.11$ and $2.31 \mathrm{~Hz}, 3 \mathrm{H}, \mathrm{H} 8), 1.99$ (dd, $J=1.10$ and $2.30 \mathrm{~Hz}, 3 \mathrm{H}, \mathrm{H} 7$ ), $3.43\left(\mathrm{t}, J=4.40 \mathrm{~Hz}, 4 \mathrm{H}, \mathrm{H} 9\right.$ and $\mathrm{H}^{\prime}$ ), $3.57(\mathrm{t}, J=4.39 \mathrm{~Hz}$, $4 \mathrm{H}, \mathrm{H} 10$ and $\left.\mathrm{H}_{10}^{\prime}\right) .{ }^{13} \mathrm{C} \mathrm{NMR}\left(\mathrm{CDCl}_{3}\right) \delta$ (ppm): 11.5, 12.1 (C7 and $\mathrm{C} 8$ ), 50.5 (C9 and C9'), 66.5 (C10 and $\mathrm{C10}^{\prime}$ ), 118.8, 137.8, 140.3, 146.7 (C2, C3, C5, and C6), 179.1, 182.8 (C1 and C4). MS (MALDI TOF) $\mathrm{m} / \mathrm{z}: 256[\mathrm{M}+\mathrm{H}]^{+}$. Calcd. for $\mathrm{C}_{12} \mathrm{H}_{14} \mathrm{CINO}_{3}(255.70)$.

2-Chloro-5,6-dimethyl-3-thiomorpholino-1,4-benzoquinone (5). Following general procedure by applying thiomorpholine $(0.110 \mathrm{~g}, 1.07 \mathrm{mmol})$, the crude residue was purified by column chromatography to furnish 5 as a dark red oil. Yield: 61\%. FTIR (ATR) U (cm-1): 2957, 2910, 2846 ( $\left.\mathrm{CH}_{\text {aliphatic }}\right), 1654$ (>C=0). ${ }^{1} \mathrm{H}$ NMR $\left(\mathrm{CDCl}_{3}\right) \delta(\mathrm{ppm}): 1.93(\mathrm{~s}, 3 \mathrm{H}, \mathrm{H} 8), 1.98(\mathrm{~s}, 3 \mathrm{H}, \mathrm{H} 7), 2.68-2.70$ $\left(\mathrm{m}, 4 \mathrm{H}, \mathrm{H} 10\right.$ and $\left.\mathrm{H}_{10} \mathrm{O}^{\prime}\right), 3.57\left(\mathrm{t}, \mathrm{J}=4.88 \mathrm{~Hz}, 4 \mathrm{H}, \mathrm{H} 9\right.$ and $\left.\mathrm{H}^{\prime}\right) .{ }^{13} \mathrm{C} \mathrm{NMR}\left(\mathrm{CDCl}_{3}\right) \delta(\mathrm{ppm}): 11.6,12.1$ (C7 and C8), 27.2 (C10 and C10'), 52.5 (C9 and C9'), 120.6, 138.0, 140.1, 147.9 (C2, C3, C5, and C6), 179.2, $182.9\left(\mathrm{C} 1\right.$ and C4). MS (+ESI) $m / z(\%): 273\left(13,[\mathrm{M}+2 \mathrm{H}]^{+}\right), 272\left(100,[\mathrm{M}+\mathrm{H}]^{+}\right)$. Calcd. $^{2}$ for $\mathrm{C}_{12} \mathrm{H}_{14} \mathrm{CINO}_{2} \mathrm{~S}(271.76)$.

\section{RESULTS AND DISCUSSION}

It is well known the reactions of 1,4-quinones containing chlorine atoms with amine, sulfur, or oxygen nucleophiles proceed by nucleophilic substitution. Herein, when 2,3-dichloro-5,6-dimethyl1,4-benzoquinone (1) was stirred with different cyclic secondary amines (pyrrolidine, piperidine, morpholine, and thiomorpholine) according to the literature (42) at $50-60{ }^{\circ} \mathrm{C}$ in the absence of a base using water as solvent, mono substituted products; 2-chloro-5,6-dimethyl-3-(pyrrolidin-1-yl)1,4-benzoquinone (2), 2-chloro-5,6-dimethyl-3-(piperidin-1-yl)-1,4-benzoquinone (3), 2-chloro5,6-dimethyl-3-morpholino-1,4-benzoquinone (4), and 2-chloro-5,6-dimethyl-3-thiomorpholino- 
1,4-benzoquinone (5) were obtained in $29-71 \%$ yield, respectively. The newly synthesized products (2-5) were characterized on the basis of FTIR, ${ }^{1} \mathrm{H} N M R,{ }^{13} \mathrm{C} N M R$, and mass spectrometry.<smiles>CC1=C(C)C(=O)C(N2CCCCC2)=C(Cl)C1=O</smiles>

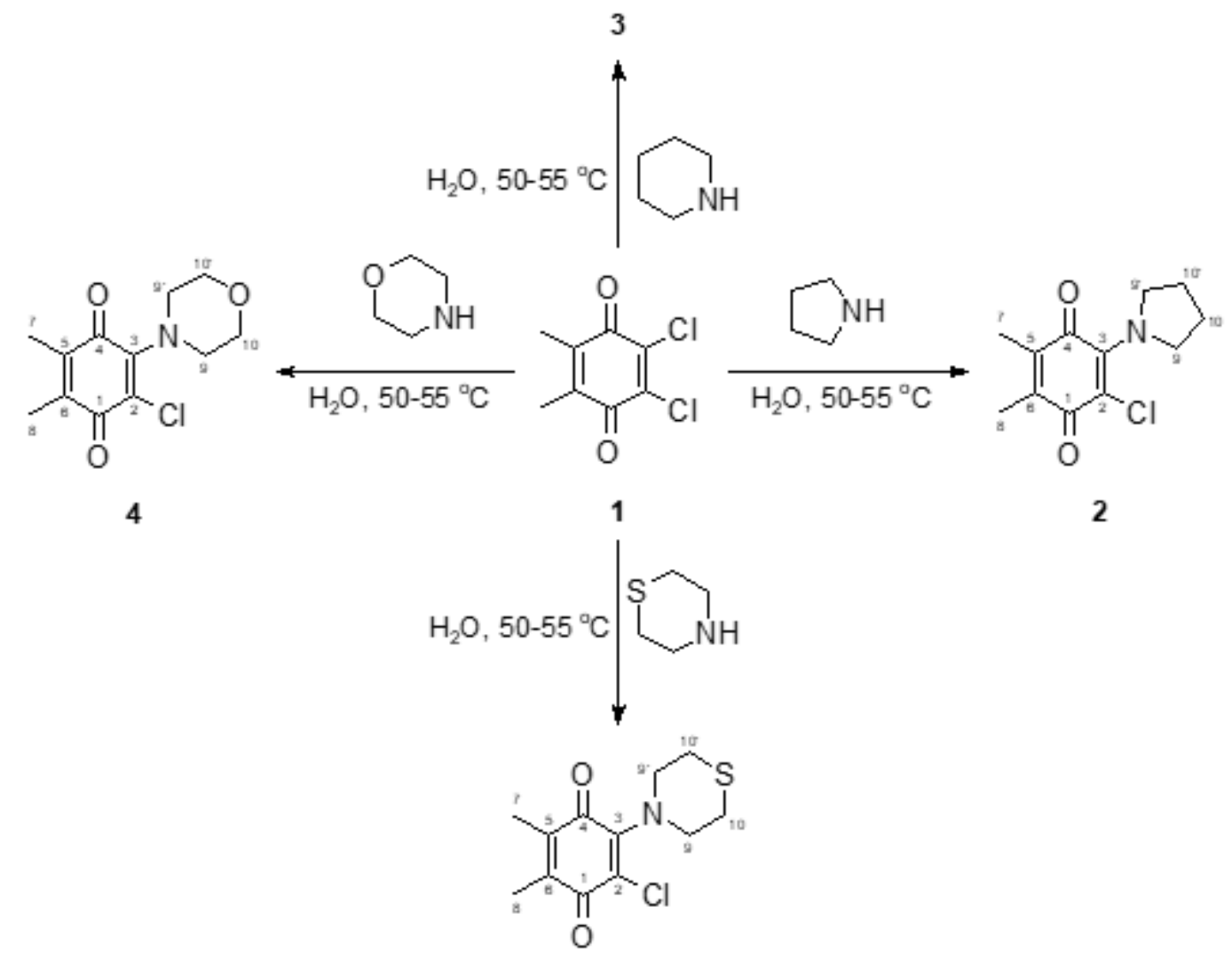

5

Scheme 1. Synthesis of cyclic aminobenzoquinones (2-5) from the reactions of 2,3-dichloro-5,6dimethyl-1,4-benzoquinone (1) with different cyclic secondary amines.

The FT-IR spectra of aminobenzoquinones (2-5) have showed characteristic carbonyl (>C=O) band at around $1650 \mathrm{~cm}^{-1}$. The ${ }^{1} \mathrm{H}$ NMR spectra of aminobenzoquinone (5) exhibited two singlets at 1.93 and $1.98 \mathrm{ppm}$ for the aliphatic methyl groups attached to the quinone moiety. On the other hand, aliphatic methyl protonds in aminobenzoquinones ( 2 and $\mathbf{4}$ ) have resonated in doublet of doublets at around 1.90 and $1.99 \mathrm{ppm}$ because of the interaction of the protons in the methyl groups. In the ${ }^{1} \mathrm{H}$ NMR spectra of $\mathbf{4}$, protons of methylene group which are adjacent to the oxygen atom have appeared as triplet at $3.57 \mathrm{ppm}$ while protons of methylene group which are adjacent to the nitrogen atom have appeared as triplet at $3.43 \mathrm{ppm}$. In the ${ }^{1} \mathrm{H}$ NMR spectra of $\mathbf{5}$, protons of methylene group 
Tuyun and Yıldız. JOTCSA. 2018;5(2) 371-380.

RESEARCH ARTICLE

next to the sulfur atom have appeared as multiplet at between $2.68-2.70 \mathrm{ppm}$ while protons in methylene group which are adjacent to the nitrogen atom have appeared as triplet at $3.57 \mathrm{ppm}$. In the ${ }^{13} \mathrm{C}$ NMR spectra of all compounds, the presence of methyl carbons could be seen as two peaks at around 11 and $12 \mathrm{ppm}$. In the ${ }^{13} \mathrm{C}$ NMR spectra of all the cyclic aminobenzoquinones (2-5), there are signals corresponding to the $>\mathrm{C}=\mathrm{O}$ carbons at around 178 and $182 \mathrm{ppm}$ as two peaks. In the mass spectrum of compounds (2-5), the accurate mass measurements of the molecular ion peaks were noticed at $m / z 240[\mathrm{M}+\mathrm{H}]^{+}, 252[\mathrm{M}-\mathrm{H}]^{+}, 256[\mathrm{M}+\mathrm{H}]^{+}$, and $272[\mathrm{M}+\mathrm{H}]^{+}$, respectively.

\section{CONCLUSION}

In conclusion, the present study describes the synthesis and characterization of new cyclic aminobenzoquinones (2-5) by a green methodology using water as solvent according to the literature reported previously by Tandon (42). The conditions are mild and good yields are obtained in the absence of any additives. We believe that these new cyclic aminobenzoquinone compounds (2-5) could be biologically important because of the fact that the compounds containing quinone skeleton with heteroatoms usually have anticancer and antimicrobial activities. Since the multifaceted biologically character of the quinone moiety provides significant potential in medicinal chemistry, further extension of our research is now ongoing in our laboratory.

\section{ACKNOWLEDGMENTS}

This work was financially supported by the Scientific Research Projects Coordination Unit of Istanbul University (Project number: FYD-2016-22584) in the supply of the equipment and materials.

\section{REFERENCES}

1. Thomson RH. Distribution of Naturally-Occurring Quinones. Pharm Weekblad. 1991;13(2):70-73.

2. Aly AA, Hassan AA. Heterocycles from Donor-Acceptor Interactions. Adv Heterocycl Chem. 2014;112:145181.

3. Mbaveng AT, Kuete V, Efferth T. Potential of Central, Eastern and Western Africa Medicinal Plants for Cancer Therapy: Spotlight on Resistant Cells and Molecular Targets. Front Pharmacol. 2017;8.

4. Duraipandiyan V, Al-Dhabi NA, Balachandran C, Raj MK, Arasu MV, Ignacimuthu S. Novel 1,5,7Trihydroxy-3-Hydroxy Methyl Anthraquinone Isolated from Terrestrial Streptomyces sp. (eri-26) with Antimicrobial and Molecular Docking Studies. Appl Biochem Biotech. 2014;174(5):1784-1794.

5. Jordao AK, Novais J, Leal B, Escobar AC, dos Santos HM, Castro HC, et al. Synthesis using microwave irradiation and antibacterial evaluation of new $\mathrm{N}, \mathrm{O}$-acetals and $\mathrm{N}, \mathrm{S}$-acetals derived from 2-amino-1,4naphthoquinones. Eur J Med Chem. 2013;63:196-201. 
6. Claessens S, Verniest G, Jacobs J, Van Hende E, Habonimana P, Van TN, et al. A survey of synthetic routes towards the pyranonaphthoquinone antibiotic pentalongin and syntheses of the corresponding nitrogen derivatives. Synlett. 2007(6):829-850.

7. Bulbule VJ, Koranne PS, Munot YS, Borate HB, Deshpande VH. Simple synthesis of two naphthoquinone antibiotics psychorubrin and pentalongin. Synthetic Commun. 2003;33(4):587-94.

8. Hosamani B, Ribeiro MF, da Silva EN, Namboothiri INN. Catalytic asymmetric reactions and synthesis of quinones. Org Biomol Chem. 2016;14(29):6913-6931.

9. Kim JS, Rhee HK, Park HJ, Lee IK, Lee SK, Suh ME, et al. Synthesis of 6-chloroisoquinoline-5,8-diones and pyrido[3,4-b]-phenazine-5,12-diones and evaluation of their cytotoxicity and DNA topoisomerase II inhibitory activity. Bioorgan Med Chem. 2007;15(1):451-457.

10. Gellis A, Kovacic H, Boufatah N, Vanelle P. Synthesis and cytotoxicity evaluation of some benzimidazole4,7-diones as bioreductive anticancer agents. Eur J Med Chem. 2008;43(9):1858-1864.

11. Belorgey D, Lanfranchi DA, Davioud-Charvet E. 1,4-Naphthoquinones and Other NADPH-Dependent Glutathione Reductase-Catalyzed Redox Cyclers as Antimalarial Agents. Curr Pharm Design. 2013;19(14):2512-2528.

12. Yildirim H, Bayrak N, Tuyun AF, Kara EM, Celik BO, Gupta GK. 2,3-Disubstituted-1,4-naphthoquinones containing an arylamine with trifluoromethyl group: synthesis, biological evaluation, and computational study. RSC Adv. 2017;7(41):25753-25764.

13. Tandon VK, Maurya HK, Yadav DB, Tripathi A, Kumar M, Shukla PK. Naphtho[2,3-b][1,4]-thiazine-5,10diones and 3-substituted-1,4-dioxo-1,4-dihydronaphthalen-2-yl-thioalkanoate derivatives: Synthesis and biological evaluation as potential antibacterial and antifungal agents. Bioorg Med Chem Lett.

2006;16(22):5883-5887.

14. Batenko N, Kricka A, Belyakov S, Turovska B, Valters R. A novel method for the synthesis of benzimidazole-based 1,4-quinone derivatives. Tetrahedron Lett. 2016;57(3):292-295.

15. Rajendran M. Quinones as photosensitizer for photodynamic therapy: ROS generation, mechanism and detection methods. Photodiagn Photodyn. 2016;13:175-187.

16. Kim KC, Liu TY, Lee SW, Jang SS. First-Principles Density Functional Theory Modeling of Li Binding: Thermodynamics and Redox Properties of Quinone Derivatives for Lithium-Ion Batteries. J Am Chem Soc. $2016 ; 138(7): 2374-2382$.

17. Lee J, Kim H, Park MJ. Long-Life, High-Rate Lithium-Organic Batteries Based on Naphthoquinone Derivatives. Chem Mater. 2016;28(7):2408-2416.

18. Hamdan AJ. Sn (II) selective 2-Amino-1,4-Naphthoquinone Derived poly(vinyl chloride) Membrane Sensors. Int J Electrochem Sc. 2010;5(2):215-231.

19. Hamdan AJ. Yttrium Selective Poly(Vinyl) Chloride Sensor Based on Derivative of 2-Amino-1,4Naphthoquinone. Int J Electrochem Sc. 2013;8(4):5838-5850.

20. Wu SP, Huang RY, Du KJ. Colorimetric sensing of Cu(II) by 2-methyl-3-[(pyridin-2-ylmethyl)-amino]-1,4naphthoquinone: $\mathrm{Cu}(\mathrm{II})$ induced deprotonation of $\mathrm{NH}$ responsible for color changes. Dalton $\mathrm{T}$. 2009(24):4735-4740.

21. Zhang QD, Piro B, Noel V, Reisberg S, Serradji N, Dong CZ, et al. An electroactive conjugated oligomer for a direct electrochemical DNA sensor. Synthetic Met. 2012;162(17-18):1496-1502.

22. Bayrak N, Tuyun AF, Yildirim H, Onul N. Spectroscopic and structural aspects of the reactions of 1,4quinones with sulfur and nitrogen nucleophiles. Cr Chim. 2014;17(6):563-569. 
Tuyun and Yıldız. JOTCSA. 2018;5(2) 371-380.

23. Tuyun AF, Bayrak N, Yildirim H, Onul N, Kara EM, Celik BO. Synthesis and In Vitro Biological Evaluation of Aminonaphthoquinones and Benzo[b]phenazine-6,11-dione Derivatives as Potential Antibacterial and Antifungal Compounds. J Chem. 2015.

24. Valderrama JA, Ibacache JA, Theoduloz C. Synthesis and antiproliferative evaluation of new isomeric ellipticine quinones. B Latinoam Caribe PI. 2014;13(6):566-574.

25. Van Aeken S, Deblander J, De Houwer J, Mosselmans T, Tehrani KA. Unexpected reaction of 2-amino1,4-naphthoquinone with aldehydes: new synthesis of naphtho[2,1-d]oxazole compounds. Tetrahedron. 2011;67(2):512-517.

26. Bala BD, Muthusaravanan S, Choon TS, Ali MA, Perumal S. Sequential synthesis of amino-1,4naphthoquinone-appended triazoles and triazole-chromene hybrids and their antimycobacterial evaluation. Eur J Med Chem. 2014;85:737-746.

27. Li J, Zhang XF, Xiang HY, Tong LJ, Feng F, Xie H, et al. C-H Trifluoromethylation of 2Substituted/Unsubstituted Aminonaphthoquinones at Room Temperature with Bench-Stable (CF3SO2)(2)Zn: Synthesis and Antiproliferative Evaluation. J Org Chem. 2017;82(13):6795-6800.

28. Lisboa CD, Santos VG, Vaz BG, de Lucas NC, Eberlin MN, Garden SJ. C-H Functionalization of 1,4Naphthoquinone by Oxidative Coupling with Anilines in the Presence of a Catalytic Quantity of Copper(II) Acetate. J Org Chem. 2011;76(13):5264-5273.

29. Sharma U, Katoch D, Sood S, Kumar N, Singh B, Thakur A, et al. Synthesis, antibacterial and antifungal activity of 2-amino-1,4-naphthoquinones using silica-supported perchloric acid (HClO4-SiO2) as a mild, recyclable and highly efficient heterogeneous catalyst. Indian J Chem B. 2013;52(11):1431-1440.

30. Sharma A, Santos IO, Gaur P, Ferreira VE, Garcia CRS, da Rocha DR. Addition of thiols to o-quinone methide: New 2-hydroxy-3-phenylsulfanylmethyl $[1,4]$ naphthoquinones and their activity against the human malaria parasite Plasmodium falciparum (3D7). Eur J Med Chem. 2013;59:48-53.

31. Shvartsberg MS, Kolodina EA, Lebedeva NI, Fedenok LG. Vicinal acetylenic derivatives of 2-amino-1,4naphthoquinone as key precursors of heterocyclic quinones. Russ Chem B+. 2012;61(3):582-588.

32. Singh MW, Karmakar A, Barooah N, Baruah JB. Variations in product in reactions of naphthoquinone with primary amines. Beilstein J Org Chem. 2007;3.

33. Tapia RA, Venegas J, Cantuarias LB. Copper Bromide-Catalyzed C-Alkylation of 2-Amino-1,4Naphthoquinone: New Synthesis of 1-Azaanthraquinones. Synthetic Commun. 2010;40(1):151-156.

34. Tseng CC, Wu YL, Chuang CP. Cerium salts in the oxidative free radical reactions between 2-amino-1,4naphthoquinones and beta-dicarbonyl compounds. Tetrahedron. 2002;58(38):7625-7633.

35. Verma SK, Singh VK. Synthesis, electrochemical, fluorescence and antimicrobial studies of 2-chloro-3amino-1,4-naphthoquinone bearing mononuclear transition metal dithiocarbamate complexes [M\{kappa S2,S-S2C-piperazine-C2H4N(H)CINQ\}(n)]. RSC Adv. 2015;5(65):53036-53046.

36. Zakharova OD, Ovchinnikova LP, Goryunov LI, Troshkova NM, Shteingarts VD, Nevinsky GA. Cytotoxicity of new alkylamino- and phenylamino-containing polyfluorinated derivatives of 1,4-naphthoquinone. Eur J Med Chem. 2010;45(6):2321-2326.

37. Khodade VS, Dharmaraja AT, Chakrapani H. Synthesis, reactive oxygen species generation and coppermediated nuclease activity profiles of 2-aryl-3-amino-1,4-naphthoquinones. Bioorg Med Chem Lett. 2012;22(11):3766-3769.

38. Ryu CK, Choi JA, Kim SH. Synthesis and antifungal evaluation of 6-(N-Arylamino)-7-methylthio-5,8quinolinediones. Arch Pharm Res. 1998;21(4):440-444.

39. Tandon VK, Yadav DB, Maurya HK, Chaturvedi AK, Shukla PK. Design, synthesis, and biological evaluation of 1,2,3-trisubstituted-1,4-dihydrobenzo[g]quinoxaline-5,10-diones and related compounds as antifungal and antibacterial agents. Bioorgan Med Chem. 2006;14(17):6120-6126. 
40. Tandon VK, Maurya HK, Mishra NN, Shukia PK. Design, synthesis and biological evaluation of novel nitrogen and sulfur containing hetero-1,4-naphthoquinones as potent antifungal and antibacterial agents. Eur J Med Chem. 2009;44(8):3130-3137.

41. Tandon VK, Maurya HK, Tripathi A, ShivaKeshava GB, Shukla PK, Srivastava P, et al. 2,3-Disubstituted1,4-naphthoquinones, $12 \mathrm{H}$-benzo[b]phenothiazine-6, 11-diones and related compounds: Synthesis and Biological evaluation as potential antiproliferative and antifungal agents. Eur J Med Chem. 2009;44(3):10861092.

42. Tandon VK, Maurya HK, Verma MK, Kumar R, Shukla PK. 'On water' assisted synthesis and biological evaluation of nitrogen and sulfur containing hetero-1,4-naphthoquinones as potent antifungal and antibacterial agents. Eur J Med Chem. 2010;45(6):2418-2426.

43. Bayrak N, Yildirim H, Tuyun AF, Kara EM, Celik BO, Gupta GK. Synthesis, Biological, and Computational Study of Naphthoquinone Derivatives Containing Heteroatoms. J Chem Soc Pakistan. 2016;38(6):1211-1221.

44. Bayrak N. Novel Straight-chained Sulfanyl Members of Arylamino-1,4-naphthoquinones: Synthesis and Characterization. JOTCSA. 2017; 4(2):597-606.

45. Yıldırım H. Synthesis and Structural Analysis of Some New Sulfanyl Amino 1,4- Naphthoquinone Derivatives. JOTCSA. 2017; 5(1):149-158.

46. Ryu CK, Song AL, Lee JY, Hong JA, Yoon JH, Kim A. Synthesis and antifungal activity of benzofuran-5-ols. Bioorg Med Chem Lett. 2010;20(22):6777-6780. 
